REVIEW ARTICLE

\title{
Nutritional Status of Children and Adolescents with Sickle Cell Disease
}

\section{Samara Agda dos Santos ${ }^{1 *}$, Cecilia Lacroix de Oliveira ${ }^{2}$, Paulo Ivo Cortez ${ }^{3}$ and Cláudia dos Santos Cople Rodrigues ${ }^{2}$}

\author{
${ }^{1}$ Specialist in Clinical Nutrition, Centro Universitário Central Paulista, Brazil \\ ${ }^{2}$ Clinical Nutrition, State University of Rio de Janeiro, Brazil \\ ${ }^{3}$ University Hospital Martagão Gesteira, Federal University of Rio de Janeiro, Brazil
}

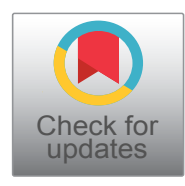

*Corresponding author: Samara Agda dos Santos, Specialist in Clinical Nutrition, Centro Universitário Central Paulista, São Paulo, Brazil, Tel: +5519-99447-3519

\begin{abstract}
Sickle cell disease (SCD) is a public health problem that interferes in the nutritional status of children and adolescents.

Objective: To describe of the nutritional status and identify the factors associated with the growth deficit or obesity of children and adolescents with sickle cell disease.

Methods: Critical analysis of originals articles published in Portuguese, English and Spanish in the electronic bases Medline, SciELO and LILACS with participants of 0 to 19 years old diagnosed with SCD.

Results: We identified 37 articles that describe low weight, short stature and overweight or obesity prevalence ranging between 3 and $100 \%, 8.2 \%$ and $24.0 \%, 1.6 \%$ and $22.4 \%$, respectively. The associated factors to the growth deficit were the increase of resting energy expenditure, the presence of low bone density, the high prevalence of low zinc and D-vitamin plasma concentration, the low consume of calcium and D-vitamin, vessel occlusion crises, increased need of transfusions and hormonal amendments presence.

Conclusion: Amendments by weight and stature were frequent; however, we note an adjustment once the presence of overweight and obesity already exists in this group. The blood transfusion, the zinc supplementation and the regular use of hydroxyurea has shown benefit in the growth of children and adolescents with sickle cell disease.
\end{abstract}

\section{Keywords}

Sickle cell disease, Growth, Nutritional status, Obesity, Children, Adolescents

\section{Introduction}

Sickle cell disease (SCD) is a multisystem disease resulted from a monogenic mutation of the beta globin from hemoglobin that originates hemoglobin $\mathrm{S}(\mathrm{HbS})$ [1]. The term sickle cell disease encompass an amendments set which hemoglobin $S$ is present, including sickle cell anemia (SCA; HbSS) and the others heterozygosis (HbSC, HbSD, S beta thalassemia, among others) [1]. $S C D$, the heritage disease with bigger prevalence in the world, is originally from Africa and can be found in a variety of countries [1].

Malnutrition between children and adolescents with SCD is described as common historically, making important to evaluate the growth and development in order to identify the growth speed decrease and the delay influential factors early once the low weight and short stature result in psychosocial [2] impacts exacerbating the clinical scenario.

Malnutrition in children and adolescents may be due to innumerable factors, such as the low consumption of food during the pain crisis or increased metabolism due to increased red blood cells turnover due to hyper hemolysis or the severity of the disease. Therefore, our initial hypothesis was that there would be a high prevalence of malnutrition in this group.

The objective of this review is to describe the nutritional status amendments prevalence and to identify 
associated factors to the growth deficit of children and adolescents with sickle cell disease.

\section{Methods}

A literature search using the Medline/PUBMED, SCOPUS, SCIELO and LILACS electronic databases for studies published up to month year was conducted. The search terms sickle cell combined with nutrition, anthropometry, growth retardation, height and weight, Body mass index (BMI) and specific micronutrients (vitamin $\mathrm{D}$ and calcium, zinc, iron, and folic acid) were used. From a total of 1402 published studies, 37 with relevant data (21 cross-sectional and 16 longitudinal) were selected.

\section{Election criteria}

The articles were eligible when fulfilling the following criteria: 1) Having participants from 0 to 19 years old; 2) Have been published in Portuguese or English or Spanish; 3) Have informed reference standards to growth evaluation; 4) Have described some factors related to the growth (bone mineral density, body composition, linear growth, growth speed, calcium, zinc and vitamin $D$ ingestion and/or serum levels, and/or different treatments effect during growth).
The accomplished studies in animals and bone-joint diseases patients and the ones that did not included sickle cell disease (HbSS) patients between the evaluated participants were excluded.

\section{Article selection}

Two researchers independently made the search. Initially the first researcher made the articles search and the abstract and key words analysis rejecting all not whose fulfilled the inclusion criteria. The second researcher did the full articles reading. We identified and eliminated duplicated articles resulting of different search methods and diversity of descriptors. The two researchers reached a consensus about the eligible articles the according to the following items: sampling procedure clarity, criteria specification of inclusion and exclusion, and properly display of the results.

We identified 46 articles for full reading. Posteriorly, we excluded 9 articles that did not match with the criteria eligibility, therefore, we included 37 articles to the review (Table 1).

\section{Data collection process}

From the eligible studies were extracted the age

Table 1: Articles characteristics included in the review according to author and publication year.

\begin{tabular}{|c|c|c|c|c|}
\hline $\begin{array}{l}\text { Authors, year } \\
\text { and country of } \\
\text { study }\end{array}$ & $\begin{array}{l}\text { Sample/Age (years/ } \\
\text { average)/Study type }\end{array}$ & Study objects & $\begin{array}{l}\text { Anthropometric } \\
\text { indicators/ } \\
\text { Growth reference } \\
\text { standard }\end{array}$ & Main Results and Conclusion \\
\hline $\begin{array}{l}\text { Stevens, et al. } \\
1986 \\
\text { Jamaica [3] }\end{array}$ & $\begin{array}{l}298 \mathrm{HbSS} \text { children and } \\
157 \mathrm{HbSC} \text { children } \\
3 \text { months to } 9 \text { years/ } \\
\text { longitudinal and } \\
\text { descriptive study. }\end{array}$ & $\begin{array}{l}\text { Evaluating the } \\
\text { growth and skeletal } \\
\text { maturation of } \\
\text { prepubertal children } \\
\text { with SCD. }\end{array}$ & $\begin{array}{l}\text { Weight and height } \\
\text { A Jamaican cohort } \\
\text { study of sickle cell } \\
\text { disease. }\end{array}$ & $\begin{array}{l}\text { Weight and height deficit associated } \\
\text { with delayed growth. }\end{array}$ \\
\hline $\begin{array}{l}\text { Singhal, et al. } \\
1994 \\
\text { Jamaica [26] }\end{array}$ & $\begin{array}{l}132 \text { children }(44 \mathrm{HbSS}, \\
44 \mathrm{HbSC} \text { and } 44 \mathrm{Hb} \\
\text { normal)/11 to } 18 \text { years } \\
\text { (average: } 17.9 \mathrm{HbSS} \text {, } \\
17.3 \mathrm{HbSC}, 17.9 \mathrm{Hb} \\
\text { normal)/longitudinal and } \\
\text { descriptive study. }\end{array}$ & $\begin{array}{l}\text { Comparing } \\
\text { the growth of } \\
\text { adolescents with } \\
\text { SCA vs. HbSC vs. } \\
\text { health controls. } \\
\text { Evaluating growth } \\
\text { speed. }\end{array}$ & $\begin{array}{l}\text { Height } \\
\text { Western Indian } \\
\text { University Hospital }\end{array}$ & $\begin{array}{l}\text { Somatic peak age postponed by } 1.6 \\
\text { years ( } 0.9 \text { to } 2.3 \text { years) in the SCA } \\
\text { subjects, however the growth of SCA } \\
\text { adolescents was normal and presented } \\
\text { no difference in the height reached at } \\
17.9 \text { years. The growth rate did not } \\
\text { delay in HbSC adolescents. }\end{array}$ \\
\hline $\begin{array}{l}\text { Warrier, et al. } \\
1994 \\
\text { USA [29] }\end{array}$ & $\begin{array}{l}34 \mathrm{SCD} \text { children }(22 \\
\mathrm{HbSS}, 4 \mathrm{HbSC}, 3 \\
\mathrm{HbSF} \text { and } 5 \text { had } \mathrm{S}^{\beta} \\
\text { thalassemia/ } 6 \text { months to } \\
16.5 \text { years/cross-sectional } \\
\text { and descriptive study. }\end{array}$ & $\begin{array}{l}\text { Determining the } \\
\text { prevalence of mild } \\
\text { and moderate } \\
\text { malnutrition in } \\
\text { patients with SCD. }\end{array}$ & $\begin{array}{l}\text { Weight }(\mathrm{W}) \text {, Height } \\
(\mathrm{H}) \text { and Weight/ } \\
\text { height Waterlow } \\
\text { classification, } 1974 \\
\text { and NCHS, } 1979\end{array}$ & $\begin{array}{l}\text { We observed weight loss ( }<80 \% \text { ) by } \\
\text { Waterlow classification in } 41 \% \text { of boys } \\
\text { and } 25 \% \text { of girls with SCD and height } \\
\text { deficit }(<90 \% \text { ) in } 25 \% \text { of boys and } 25 \% \\
\text { of girls with SCD. }\end{array}$ \\
\hline $\begin{array}{l}\text { Soliman, et al. } \\
1995 \\
\text { Oman [22] }\end{array}$ & $\begin{array}{l}90 \text { prepubertal children } \\
\text { (Tanner } 1)(25 \text { with GHD, } \\
15 \mathrm{HbSS} \text { and GHD, } 30 \\
\text { with normal variants of } \\
\text { short stature and } 20 \text { with } \\
\text { normal stature)/4 to } 10 \\
\text { years/cross-sectional and } \\
\text { case- control study. }\end{array}$ & $\begin{array}{l}\text { Comparing growth, } \\
\text { pituitary function } \\
\text { and CT evaluation } \\
\text { of the hypothalamic- } \\
\text { pituitary area in } \\
\text { children with GHD, } \\
\text { children with SCD } \\
\text { and GHD, children } \\
\text { of the same age with } \\
\text { short stature and } \\
\text { normal children of } \\
\text { the same age. }\end{array}$ & $\begin{array}{l}\text { BMI Tanner } \\
\text { classifications, } \\
1976\end{array}$ & $\begin{array}{l}\text { All children with sickle cell anemia and } \\
\text { empty saddle had BMI below the 5th } \\
\text { percentile for age. }\end{array}$ \\
\hline
\end{tabular}




\begin{tabular}{|c|c|c|c|c|}
\hline $\begin{array}{l}\text { Soliman, et al. } \\
1997 \\
\text { Oman [21] }\end{array}$ & $\begin{array}{l}21 \text { HbSS prepubertal } \\
\text { children with SCA and } \\
\text { short stature/age of } \\
\text { children and GHD: } 6.6 \\
\text { years; SCA and normal } \\
\text { response to GH: } 7.3 \\
\text { years; GHD isolated: } 7.3 \\
\text { years/cross-sectional and } \\
\text { descriptive study. }\end{array}$ & $\begin{array}{l}\text { Testing the } \\
\text { hypothesis that SCA } \\
\text { is associated with } \\
\text { abnormalities of the } \\
\text { IGF-1, IGFB- } 3 \text { and } \\
\text { GH resistance axes. }\end{array}$ & $\begin{array}{l}\text { Height/age and } \\
\text { Weight/age } \\
\text { French sickle cell } \\
\text { disease group. }\end{array}$ & $\begin{array}{l}\text { Basal concentrations of IGF-1 and } \\
\text { IGFBP-3 were significantly lower in } \\
\text { the group with SCA and deficient GH } \\
\text { secretion. Children with SCA have lower } \\
\text { significant IGF-1 production in response } \\
\text { to GH, suggesting partial resistance to } \\
\text { GH. BMI did not show any difference } \\
\text { between the groups, but } 9 \text { of the } 21 \\
\text { showed slower linear growth speed } \\
\text { and lower concentrations of IGF-I and } \\
\text { IGFBP-3. }\end{array}$ \\
\hline $\begin{array}{l}\text { de } \\
\text { Montalembert, } \\
\text { et al. } 1997 \\
\text { France [36] }\end{array}$ & $\begin{array}{l}35 \text { children and } \\
\text { adolescents with SCD/3 } \\
\text { to } 20 \text { years (average of } \\
11 \text { years)/longitudinal and } \\
\text { descriptive study. }\end{array}$ & $\begin{array}{l}\text { Observing the safety } \\
\text { and efficiency of } \\
\text { HU in children with } \\
\text { severe SCD. }\end{array}$ & $\begin{array}{l}\text { Weight/height } \\
\text { NCHS, } 1977\end{array}$ & $\begin{array}{l}\text { The HU had good tolerance in short } \\
\text { and medium term. No difference in } \\
\text { growth speed in any of the three groups } \\
\text { of children and adolescents. Z-scores } \\
\text { were similar at the beginning of the } \\
\text { study, after } 1 \text { year and after } 2 \text { years of } \\
\text { treatment, excluding the adverse effect } \\
\text { of HU on growth in this cohort. }\end{array}$ \\
\hline $\begin{array}{l}\text { Leonard, et al. } \\
1998 \\
\text { USA [14] }\end{array}$ & $\begin{array}{l}104 \mathrm{HbSS} \text { children and } \\
\text { adolescents/4 to } 18 \\
\text { years/cross-sectional and } \\
\text { descriptive study. }\end{array}$ & $\begin{array}{l}\text { Determining the } \\
\text { relation of plasma } \\
\text { zinc to growth and } \\
\text { maturation of children } \\
\text { with SCA. }\end{array}$ & $\begin{array}{l}\text { Weight and height } \\
\text { HUG-KIDS study }\end{array}$ & $\begin{array}{l}44 \% \text { of the children had low plasma } \\
Z n \text {. They had a significant decrease } \\
\text { in weight }(-1.00 \pm 0.15 \mathrm{ZS} \text { vs. }-0.14 \pm \\
0.13 \mathrm{ZS}, \mathrm{p}=0.003) \text { and height }(-0.78 \pm \\
0.15 \mathrm{ZS} \text { vs. }-0.15 \pm 0.14 \mathrm{ZS}, \mathrm{p}=0.003) \\
\text { compared to those with normal } \mathrm{Zn} \text {. }\end{array}$ \\
\hline $\begin{array}{l}\text { Kinney, et al. } \\
1999 \\
\text { USA [41] }\end{array}$ & $\begin{array}{l}84 \mathrm{HbSS} \text { children/9.8 } \pm \\
3.2 \text { years (average of } 9.1 \\
\text { years)/longitudinal and } \\
\text { descriptive study. }\end{array}$ & $\begin{array}{l}\text { Determining the } \\
\text { maximum tolerated } \\
\text { dose of HU and treat } \\
\text { a cohort of } 50 \text { severe } \\
\text { children for one } \\
\text { year receiving the } \\
\text { maximum tolerated } \\
\text { dose. }\end{array}$ & $\begin{array}{l}\text { Weight and height } \\
\text { University of } \\
\text { South Alabama } \\
\text { Comprehensive } \\
\text { Sickle Center } \\
\text { Clinics }\end{array}$ & $\begin{array}{l}\text { HU had no adverse effect on growth. } \\
\text { At each } 6 \text {-month interval, mean weight } \\
\text { and height increased significantly ( } p< \\
0.0001) \text {. }\end{array}$ \\
\hline $\begin{array}{l}\text { Cipollotti, et al. } \\
2000 \\
\text { Brazil [27] }\end{array}$ & $\begin{array}{l}76 \text { children and } \\
\text { adolescents with SCA/ } \\
\text { mean age of } 9 \text { years } \\
\text { old/cross-sectional and } \\
\text { descriptive study. }\end{array}$ & $\begin{array}{l}\text { Describing the } \\
\text { growth standard in } \\
\text { children with SCA. }\end{array}$ & $\begin{array}{l}\text { Weight and } \\
\text { Height in standard } \\
\text { deviation scores } \\
\text { (SD). } \\
\text { Collaboration } \\
\text { Centers from USA } \\
\text { and Europe. }\end{array}$ & $\begin{array}{l}100 \% \text { of children and adolescents were } \\
\text { underweight (NCHS). } \\
\text { Average height lower than the NCHS } \\
\text { standard at most ages, except for } \\
7 \text {-year-old children. Only 15-year-old } \\
\text { girls had a short stature. }\end{array}$ \\
\hline $\begin{array}{l}\text { Walters, et al. } \\
2000 \\
\text { USA [42] }\end{array}$ & $\begin{array}{l}50 \text { children with } S C D / 3.3 \\
\text { to } 14.0 \text { years (average } \\
\text { of } 9.4 \text { years)/longitudinal } \\
\text { study. }\end{array}$ & $\begin{array}{l}\text { Evaluating the late } \\
\text { effects of bone } \\
\text { marrow transplant in } \\
\text { a cohort of children } \\
\text { with SCD. }\end{array}$ & $\begin{array}{l}\text { Weight/height } \\
\text { NCHS, } 1977\end{array}$ & $\begin{array}{l}\text { Stature growth improved from }-0.7 \text { zs } \\
\text { (before) to }-0.2 \text { zs after } 48 \text { months of } \\
\text { transplanted. }\end{array}$ \\
\hline $\begin{array}{l}\text { Fung, et al. } \\
2001 \text { USA [8] }\end{array}$ & $\begin{array}{l}8 \text { prepubertal children } \\
\text { with SCA/5.2-9.6 } \\
\text { years (average of } 6.9 \\
\text { years)/longitudinal with } \\
\text { intervention study. }\end{array}$ & $\begin{array}{l}\text { Comparing the } \\
\text { energy expenditure } \\
\text { of rest, growth } \\
\text { and food intake } \\
\text { before and after the } \\
\text { implementation of HU } \\
\text { therapy in children } \\
\text { with SCA. }\end{array}$ & $\begin{array}{l}\text { Child: Weight/age, } \\
\text { Weight/height and } \\
\text { Height/age } \\
\text { Adolescent: BMI/A } \\
\text { NCHS, } 1977\end{array}$ & $\begin{array}{l}100 \% \text { of children gained weight, height, } \\
\text { fat and fat free mass. HU increased the } \\
\mathrm{Hb} \text { from } 8.0 \mathrm{~g} / \mathrm{dL} \text { at the beginning to } \\
8.4 \mathrm{~g} / \mathrm{dL} \text { at the end of the study, which } \\
\text { may improve growth as well as reduce } \\
\text { hypermetabolism. }\end{array}$ \\
\hline $\begin{array}{l}\text { Luporini, et al. } \\
2001 \\
\text { Brazil [23] }\end{array}$ & $\begin{array}{l}41 \text { children with SCA/ } 2.8 \\
\text { to } 15.0 \text { years (average of } \\
8.5) / \text { cross-sectional and } \\
\text { descriptive study. }\end{array}$ & $\begin{array}{l}\text { Analyzing the } \\
\text { relation between } \\
\text { growth in children } \\
\text { with SCA and the } \\
\text { different betaglobin } \\
\text { haplotypes, as well } \\
\text { as components of } \\
\text { IGF-1 and IGFBP-3. }\end{array}$ & $\begin{array}{l}\text { Weight/age and } \\
\text { Height/age NCHS, } \\
1977\end{array}$ & $\begin{array}{l}\text { Plasma concentrations of IGF-1 and } \\
\text { IGFBP-3 were low in all patients with } \\
\text { SCA. The positive relation between } \\
\text { hematocrit and Hb F with total IGF-1, } \\
\text { free/total IGF-1 and IGFBP-3 in patients } \\
\text { with SCA showed that the growth delay } \\
\text { of these patients may relates to intrinsic } \\
\text { factors of the disease. } \\
\text { Patients with the CAR/CAR haplotype } \\
\text { had significantly slower growth speed } \\
\text { compared to those with BEN/BEN. }\end{array}$ \\
\hline
\end{tabular}




\begin{tabular}{|c|c|c|c|c|}
\hline $\begin{array}{l}\text { Silva, et al. } \\
2002 \\
\text { Brazil [18] }\end{array}$ & $\begin{array}{l}100 \text { children ( } 73 \text { with } \mathrm{Hb} \text { SS } \\
\text { and } 27 \text { with } \mathrm{Hb} \text { SC) under } \\
8 \text { years old/longitudinal and } \\
\text { descriptive study. }\end{array}$ & $\begin{array}{l}\text { Evaluating the } \\
\text { growth of children } \\
\text { with HbSS and } \\
\text { HbSC for a year and } \\
\text { correlating it with } \\
\text { hematological data. }\end{array}$ & $\begin{array}{l}\text { Weight/age, } \\
\text { Height/age and } \\
\text { Weight/height } \\
\text { NCHS, } 1977\end{array}$ & $\begin{array}{l}\text { Malnutrition current in } 8.2 \%, 9.6 \% \\
\text { and } 1.4 \% \text { of the SCA children when } \\
\text { evaluated W/A, H/A and } \mathrm{W} / \mathrm{H} \text {, } \\
\text { respectively. In children with } \mathrm{HbSC} \\
\text { were } 14.8 \%, 3.7 \% \text { and } 0 \% \text { respectively } \\
\text { The reduction of } \mathrm{Hb} \text { in } \mathrm{HbSS} \text { and } \mathrm{HbSC} \\
\text { children (mean of } 7.5 \mathrm{~g} / \mathrm{dl} \text { and } 10.2 \mathrm{~g} / \mathrm{dl} \\
\text { respectively) might relates to growth. }\end{array}$ \\
\hline $\begin{array}{l}\text { Barden, et al. } \\
2002 \\
\text { USA [32] }\end{array}$ & $\begin{array}{l}66 \text { children and } \\
\text { adolescents }(36 \mathrm{HbSS} \text { and } \\
30 \text { controls }) / 5 \text { to } 18 \text { years } \\
\text { (average: } 11.3 \pm 3.8 \mathrm{HbSS} \\
11.2 \pm 3.2 \text { controls)/cross- } \\
\text { sectional and descriptive } \\
\text { study. }\end{array}$ & $\begin{array}{l}\text { Evaluating } \\
\text { growth, nutritional } \\
\text { status and body } \\
\text { composition in } \\
\text { children with SCA } \\
\text { and without disease } \\
\text { (control). }\end{array}$ & $\begin{array}{l}\text { Weight, height and } \\
\text { BMI Sickle cell } \\
\text { Clinic of Western } \\
\text { Indian University }\end{array}$ & $\begin{array}{l}\text { Weight, W/A, and H/A in zs were } \\
\text { significantly lower in the SCA group. } \\
\mathrm{H} / \mathrm{A}: \mathrm{HbSS}=0.4 \pm 1.1 \mathrm{zs} \text { vs. control = } \\
0.5 \pm 1.0 \mathrm{zs} \text { W/A: } \mathrm{HbSS}=0.8 \pm 1.1 \mathrm{zs} \\
\text { vs. control }=0.3 \pm 1.0 \mathrm{zs} \text {. }\end{array}$ \\
\hline $\begin{array}{l}\text { Singhal, et al. } \\
2002 \\
\text { Jamaica [37] }\end{array}$ & $\begin{array}{l}72 \text { children }(41 \mathrm{HbSS} \text { and } \\
31 \text { controls)/3 to } 6 \text { years } \\
\text { (average: HbSs: } 4.1 \pm \\
0.92,+4.2 \pm 1.0 \text {; Controls: } \\
4.1 \pm 0.8+1.1 \pm 1.0) / \text { cross- } \\
\text { sectional and descriptive } \\
\text { study. }\end{array}$ & $\begin{array}{l}\text { Testing the } \\
\text { hypothesis that } \\
\text { energy consumption } \\
\text { in relation to resting } \\
\text { metabolic rate is } \\
\text { lower in children } \\
\text { with SCA than in } \\
\text { control subjects }\end{array}$ & $\begin{array}{l}\text { Weight and height } \\
\text { Study HUG-KIDS }\end{array}$ & $\begin{array}{l}\text { Children with SCA did not differ } \\
\text { significantly from controls group of age, } \\
\text { weight, body mass index and energy } \\
\text { intake, but the resting metabolic rate } \\
\text { was higher in children with SCA. }\end{array}$ \\
\hline $\begin{array}{l}\text { Zemel, et al. } \\
2002 \text { USA [15] }\end{array}$ & $\begin{array}{l}42 \text { HbSS prepubertal } \\
\text { children/4 to } 10 \text { years } \\
\text { (average: } 7.1 \text { years)/ } \\
\text { longitudinal with random } \\
\text { intervention study. }\end{array}$ & $\begin{array}{l}\text { Determining the } \\
\text { effects of zinc } \\
\text { supplementation on } \\
\text { growth and body } \\
\text { composition in } \\
\text { children with SCA. }\end{array}$ & $\begin{array}{l}\text { Weight/age, } \\
\text { Height/age and } \\
\text { BMI/A } \\
\text { NCHS, } 1977\end{array}$ & $\begin{array}{l}15 \% \text { had } \mathrm{Zn} \text { deficiency }(<10.7 \\
\mathrm{mmol} / \mathrm{L}) \text { and when they received } \\
\text { supplementation of } 10 \mathrm{mg} / \text { day they had } \\
0.66 \mathrm{~cm} \text { greater stature gain than the } \\
\text { control. }\end{array}$ \\
\hline $\begin{array}{l}\text { Wang, et al. } \\
2002 \text { USA [39] }\end{array}$ & $\begin{array}{l}68 \mathrm{HbSS} \text { children and } \\
\text { adolescents/5 to } 16 \\
\text { years/longitudinal with } \\
\text { intervention study. }\end{array}$ & $\begin{array}{l}\text { Evaluating the effect } \\
\text { of HU on the growth } \\
\text { of children with } \\
\text { SCA. }\end{array}$ & $\begin{array}{l}\text { Weight/age, } \\
\text { Height/age and } \\
\text { BMI/A } \\
\text { NCHS, } 2000\end{array}$ & $\begin{array}{l}\text { Treatment with HU had no adverse } \\
\text { effect on height or weight gain } \\
\text { or pubertal development. Weight } \\
\text { during pre-treatment and treatment } \\
\text { in the HUG-KIDS group was } 11 \% \text { to } \\
27 \% \text { higher than in the Sickle Cell } \\
\text { Cooperative Study group. Height of } \\
\text { children HUG-KIDS pre-treatment from } \\
7 \text { years old was } 3 \text { to } 8 \mathrm{~cm} \text { higher than } \\
\text { height in the Cooperative Study of } \\
\text { Sickle Cell Disease }(p<0.05) \text {. }\end{array}$ \\
\hline $\begin{array}{l}\text { Buison, et al. } \\
2004 \\
\text { USA [16] }\end{array}$ & $\begin{array}{l}65 \mathrm{HbSS} \text { children and } \\
\text { adolescents/5 to } 18 \text { years/ } \\
\text { cross-sectional and } \\
\text { descriptive study. }\end{array}$ & $\begin{array}{l}\text { Examining the } \\
\text { vitamin D status in } \\
\text { children with HbSS } \\
\text { and its relation to } \\
\text { the time and dietary } \\
\text { intake. }\end{array}$ & $\begin{array}{l}\text { Weight/age, } \\
\text { Height/age and } \\
\text { BMI/A } \\
\text { NCHS, } 2000\end{array}$ & $\begin{array}{l}\text { Low serum vitamin D levels were highly } \\
\text { prevalent in black children with SCA. } \\
\text { Vitamin D status was associated with } \\
\text { the year's season and food intake. } \\
\text { H/A, W/A and BMI/A in ZS were not } \\
\text { associated with the vitamin D status. }\end{array}$ \\
\hline $\begin{array}{l}\text { Buison, et al. } \\
2005 \\
\text { USA [12] }\end{array}$ & $\begin{array}{l}90 \mathrm{HbSS} \text { children and } \\
\text { adolescents/4 to } 19 \text { years/ } \\
\text { longitudinal and descriptive } \\
\text { study. }\end{array}$ & $\begin{array}{l}\text { Determining the } \\
\text { impact of SCA on } \\
\text { body BMC and body } \\
\text { bone area in relation } \\
\text { to height and } \\
\text { body composition } \\
\text { compared to the } \\
\text { healthy individual. }\end{array}$ & $\begin{array}{l}\text { Weight/age, } \\
\text { Height/age and } \\
\text { BMI/A } \\
\text { NCHS, } 2000\end{array}$ & $\begin{array}{l}\text { Low BMD (<3th percentile) for total } \\
\text { body/age, bone area and BMC/age } \\
\text { ( } 14 \% \text { and } 9 \% \text {, respectively). Low } \\
\text { calcium intake by } 75 \% \text { and vitamin D } \\
\text { by } 77 \% \text {. Serum vitamin D deficiency } \\
\text { was } 66 \% \text {. }\end{array}$ \\
\hline $\begin{array}{l}\text { Wang, et al. } \\
2005 \text { USA [19] }\end{array}$ & $\begin{array}{l}94 \mathrm{HbSS} \text { children and } \\
\text { adolescents/2 to } 16 \text { years/ } \\
\text { longitudinal and descriptive } \\
\text { study. }\end{array}$ & $\begin{array}{l}\text { Determining if long- } \\
\text { term transfusion } \\
\text { improves growth in } \\
\text { children with SCA. }\end{array}$ & $\begin{array}{l}\text { Height/age, weight/ } \\
\text { age and BMI } \\
\text { Children's Hospital } \\
\text { Sickle Cell Integral } \\
\text { Center, Oakland }\end{array}$ & $\begin{array}{l}\text { Children who received long-term } \\
\text { transfusions had an increase in height, } \\
\text { weight and BMI throughout the study } \\
\text { (increase from } 26.7 \mathrm{~kg} \text { to } 35.3 \mathrm{~kg} \text {, from } \\
127 \mathrm{~cm} \text { to } 140 \mathrm{~cm} \text {, from } 15.8 \mathrm{~kg} / \mathrm{m}^{2} \text { to } \\
17.4 \mathrm{~kg} / \mathrm{m}^{2} \text {, respectively) compared } \\
\text { to children on standard treatment. } \\
\text { Increased post-transfusion } \\
\mathrm{Hb} \text { (from } 7.2 \mathrm{~g} / \mathrm{dl} \text { to } 8.8 \mathrm{~g} / \mathrm{dl} \text { ) can } \\
\text { improve growth by decreasing energy } \\
\text { expenditure. }\end{array}$ \\
\hline
\end{tabular}




\begin{tabular}{|l|l|}
\hline Lal, et al. 2006 & 25 HbSS children and \\
USA [11] & adolescents with severe \\
& manifestations/9 to 19 \\
& years (average: 12.8 \\
& years)/cross-sectional and \\
descriptive study.
\end{tabular}

Eggleston, et al. $53 \mathrm{HbSS}$ children and 2007

USA [40] adolescents/< 16 years/ Multicentric, longitudinal and descriptive study.
Evaluating BMD and Initial and final risk factors for low bone mineralization SCA.

Defining the risks and benefits of HCT. in children with weight and height. femur and $56 \%$ in the lumbar spine.

HCT Multicenter $\quad 60 \%$ low serum calcium $(<1,300 \mathrm{mg})$ Study for sickle cell and low vitamin D level $(<7.5 \mathrm{nM}$ in anemia $\quad 30 \%,<50 \mathrm{nM}$ in $74 \%$ and $\leq 62.5 \mathrm{nM}$ in $100 \%$ of those evaluated).

Weight and Small children with SCA did not show Height Pediatric prejudice in growth by HCT; however, Hematology growth performs may decrease if HCT Outpatient Clinic, near or during the growth peak in Duke University adolescence.

Medical Center.

Boys in the HUG-KIDS (HU) group are $2.7 \mathrm{~kg}$ heavier than the HCT group.

Boys in the HUG-KIDS (Pre) group are approximately $4 \mathrm{~cm}$ taller the $\mathrm{TCH}$ group. Lower levels of IGFBP-3 in children with short stature when compared to

Collett-Solberg, 22 children with $\mathrm{HbSS} / 15$ et al. 2007 USA with height below the 25th [24] percentile - mean age $10.45 \pm 3.14$ years and 7 with height above the 50th percentile-mean of $12.0 \pm$ 3.63 years/cross-sectional and descriptive study.

Zemel, et al. $148 \mathrm{HbSS}$ children/0 to 18 2007 USA [20] (average: $9.1 \pm 4.7$ years)/ prospective, longitudinal and descriptive study.

Verifying if changes Height/age,

in the IGF-I axis are Weight/height, involved with growth BMI/A NCHS, 2000 the normal growth group $(p=0.028)$. deficit in children with HbSS.

\section{Describing the Weight/age,} longitudinal standards of growth in a group Height/age and $\mathrm{BMI} / \mathrm{A}$ Children with SCA have abnormalities in the IGF-1 axis, which worsen with age.

Mean height of normal growing children was not statistically different from the height of patient's parents with short stature $(p=0.18)$.

Growth in height, weight or BMI decreased in $84 \%$ of individuals; $38 \%$ were below the 5 th percentile in one or more measurements. Puberty of children with

SCA and identifying modifiable factors associated with below ideal growth.

Fung, et al. $80 \mathrm{HbSS}$ children/ ${ }^{3}$ 2008 USA [10] average: $11.2 \pm 4.6$ ( 4.5 to 19.0 years $)^{\circ}$ average: 10.0 \pm 3.8 (4.5 to 19.1 years)/ longitudinal and descriptive study.

\begin{tabular}{l|l} 
& \\
\begin{tabular}{l|l} 
Rhodes, et al. \\
2009 \\
USA [9]
\end{tabular} & $\begin{array}{l}33 \mathrm{HbSS} \text { children/10 to } \\
13 \text { years/longitudinal and } \\
\text { descriptive study. }\end{array}$ \\
\hline
\end{tabular}

Animasahun, et 200 children $(100 \mathrm{HbSS}$ al. 2011 Nigeria [30]
Describing bone

remodeling in

children with SCA

to determine if

there is a relation between markers of bone remodeling and alteration of bone density and/or growth parameters.

Systematically

studying the correlations between growth, hemoglobin and energy expenditure in children with SCA compared to healthy controls.

\section{Determining}

the influence of socioeconomic status on the nutritional status of children with steady state SCA.
NCHS, 2000 postponed in 1-2 years and mean age of menarche was 13.2 years. Bone age delayed by $1.3 \pm 1.5$ years in the age group of 10 to 15 years old.

Weight, height and Reduced BMC corrected for age in the BMC NCHS, 2000 last year of follow-up.

Weight-for-age Z-score Males: $-1.2 \pm$ $1.1(-3.2$ to 1.1$)$

Females: $-0.5 \pm 0.9(-2.1$ to 1.5$)$

Height-for-age Z-score Males: $-0.9 \pm$ $1.1(-3.2$ to 1.7$)$

Females: $-0.1 \pm 1.0(-2.7$ to 1.8$)$

Weight/age, Decrease of growth speed in Height/age and $\mathrm{BMI} / \mathrm{A}$ children with SCA was independently associated with the decrease of $\mathrm{Hb}$

NCHS, 2000 concentration and increase of total energy expenditure. There was no difference in weight or BMl at beginning of the study and after 1 or 2 years.
Weight/age, Height/age and BMI/A

NCHS, 2000 and 100 normal controls/1 to 10 years/prospective, cross-sectional and analytical study.
Smallest range of weight and $\mathrm{W} / \mathrm{H}$ in SCA patients than in the controls, however, there was no significant difference in height $(p=0.06)$ and in BMI/A ( $p=0.12)$ among the SCA patients and controls $(p<0.01)$. The mean values of body weight, height and BMI of the SCA subjects were consistently lower than those of the $\mathrm{NCHS}$ standards, and the difference increased with advancing age, affecting more males. 


\begin{tabular}{|c|c|c|c|c|}
\hline $\begin{array}{l}\text { Dougherty, et } \\
\text { al. } 2011 \\
\text { USA [31] }\end{array}$ & $\begin{array}{l}151 \text { children }(35 \mathrm{HbSS} \text { and } \\
103 \text { controls)/5 to } 3 \text { years } \\
\text { (controls average: } 8.6 \pm 1.8 \\
\text { and HbSS: } 9.0 \pm 2.2) / \text { cross- } \\
\text { sectional and descriptive } \\
\text { study. }\end{array}$ & $\begin{array}{l}\text { Analyzing the } \\
\text { maximum muscle } \\
\text { strength and peak } \\
\text { power in children } \\
\text { with SCA. }\end{array}$ & $\begin{array}{l}\text { Height/age, } \\
\text { Weight/height and } \\
\text { BMI/A } \\
\text { WHO, } 2006 \text { and } \\
2007\end{array}$ & $\begin{array}{l}\text { Maximum muscle strength and peak } \\
\text { power reduced in children with SCA } \\
\text { compared to controls, in addition there } \\
\text { was growth and body composition deficit. } \\
\text { Z scores for height, weight and BMI } \\
\text { significantly lower in children with SCA. }\end{array}$ \\
\hline $\begin{array}{l}\text { Souza, et al. } \\
2011 \text { Brazil [5] }\end{array}$ & $\begin{array}{l}161 \text { children and } \\
\text { adolescents/0 to } 14 \text { years } \\
\text { (average: } 7.4 \text { years)/cross- } \\
\text { sectional and descriptive } \\
\text { study. }\end{array}$ & $\begin{array}{l}\text { Evaluating the } \\
\text { anthropometric } \\
\text { nutritional status } \\
\text { of children and } \\
\text { adolescents with } \\
\text { SCD. }\end{array}$ & $\begin{array}{l}\text { Weight/height and } \\
\text { BMI/A WHO, } 2006\end{array}$ & $\begin{array}{l}\text { W/H: } 2.2 \% \text { of short stature, } 3.6 \% \\
\text { of thinness, } 94.6 \% \text { of eutrophy and } \\
1.8 \% \text { of overweight BMI/A: } 5.7 \% \text { of } \\
\text { thinness, } 92.7 \% \text { of eutrophy and } 1.6 \% \\
\text { of overweight }\end{array}$ \\
\hline $\begin{array}{l}\text { Nikhar, et al. } \\
2012 \\
\text { India [28] }\end{array}$ & $\begin{array}{l}105 \mathrm{HbSS} \text { children/8 to } 15 \\
\text { years (average: rural area } \\
9 \pm 2.1 \text { years; urban area } 8 \\
\pm 2.2 \text { years)/cross sectional } \\
\text { and descriptive study. }\end{array}$ & $\begin{array}{l}\text { Performing a } \\
\text { comparative study } \\
\text { using anthropometric } \\
\text { and hematological } \\
\text { parameters in HbSS } \\
\text { children from urban } \\
\text { and rural areas of } \\
\text { India. }\end{array}$ & $\begin{array}{l}\text { Weight/age, } \\
\text { Height/age and } \\
\text { BMI/A } \\
\text { WHO, } 2007\end{array}$ & $\begin{array}{l}\text { Rural HbSS children presented lower } \\
\text { weight compared to urban children. }\end{array}$ \\
\hline $\begin{array}{l}\text { Pinho, et al. } \\
2012 \text { Brazil [17] }\end{array}$ & $\begin{array}{l}12 \mathrm{HbSS} \text { children/ } \\
\text { preschool and school/ } \\
\text { cross-sectional and } \\
\text { descriptive study. }\end{array}$ & $\begin{array}{l}\text { Evaluating the } \\
\text { anthropometric and } \\
\text { dietary profile of } \\
\text { children with SCA in } \\
\text { a deprived area of } \\
\text { the city of Januária } \\
\text { (MG). }\end{array}$ & BMI NCHS, 2000 & $\begin{array}{l}91.7 \% \text { of eutrophy, } 8.3 \% \text { of thinness; } \\
83.3 \% \text { of suitable weight for age and } \\
16.7 \% \text { of low weight for age; } 8.3 \% \\
\text { of short stature for age. Most of the } \\
\text { children presented eutrophy, however, } \\
\text { also inadequate dietary intake. }\end{array}$ \\
\hline $\begin{array}{l}\text { Chawla, et al. } \\
2013 \\
\text { USA [4] }\end{array}$ & $\begin{array}{l}675 \mathrm{HbSS} \text { children and } \\
\text { adolescents/2 to } 19 \text { years } \\
\text { (average: } 10.8 \text { years)/ } \\
\text { multicentric/retrospective } \\
\text { and descriptive study. }\end{array}$ & $\begin{array}{l}\text { Determining the } \\
\text { prevalence of } \\
\text { underweight, normal } \\
\text { weight, overweight } \\
\text { and obesity in } \\
\text { a multicenter } \\
\text { study with urban } \\
\text { population of } \\
\text { children with SCA. }\end{array}$ & $\begin{array}{l}\text { Weight, height and } \\
\text { BMI NCHS, } 2000\end{array}$ & $\begin{array}{l}22.4 \% \text { of overweight or obesity and } \\
6.7 \% \text { underweight. } 38 \% \text { of increase in } \\
\text { the possibility of overweight/obesity for } \\
\text { every } 1 \mathrm{~g} / \mathrm{dL} \text { increase in Hb levels. }\end{array}$ \\
\hline $\begin{array}{l}\text { Özen, et al. } \\
2013 \text { Turkey } \\
{[13]}\end{array}$ & $\begin{array}{l}50 \mathrm{HbSS} \text { children and } \\
\text { adolescents/< } 18 \text { years } \\
\text { (average: } 13.1 \pm 2.9 \\
\text { years)/cross-sectional and } \\
\text { descriptive study. }\end{array}$ & $\begin{array}{l}\text { Determining the } \\
\text { frequency and } \\
\text { risk factors for } \\
\text { abnormalities } \\
\text { in growth, } \\
\text { development, } \\
\text { puberty, thyroid } \\
\text { function, bone } \\
\text { and carbohydrate } \\
\text { metabolism in } \\
\text { children and } \\
\text { adolescents with } \\
\text { sickle cell anemia. }\end{array}$ & $\begin{array}{l}\text { Height/age and } \\
\text { Weight/height } \\
\text { WHO, } 2006\end{array}$ & $\begin{array}{l}\text { Weight and height of } 24 \% \text { were }-2 \\
\text { SD below normal and } 8 \% \text { presented } \\
\text { malnutrition. Growth hormone } \\
\text { deficiency in } 2 \% \text { of female patients, } \\
\text { and hypothyroidism in } 6 \% ; 11.1 \% \text { had } \\
\text { osteopenia and } 2.2 \% \text { had osteoporosis } \\
\text { (vertebral), while } 11.1 \% \text { had osteopenia } \\
\text { (femoral neck). Vitamin D deficiency } \\
\text { occurred in } 63.2 \% \text { and insufficient in } \\
18.4 \% \text { of patients. }\end{array}$ \\
\hline $\begin{array}{l}\text { Bavle, et al. } \\
2014 \text { USA [33] }\end{array}$ & $\begin{array}{l}36 \mathrm{HbSS}^{\mathrm{H}} \text { and } \mathrm{HbSS}^{\beta} \\
\text { Thalassemia children/ } \\
\text { retrospective and } \\
\text { descriptive study. }\end{array}$ & $\begin{array}{l}\text { Analyzing the growth } \\
\text { of } 36 \text { children with } \\
\text { HbSS and } \mathrm{HbS}^{\beta} \\
\text { Thalassemia in } \\
\text { LTE, with average } \\
\text { duration of almost } 5 \\
\text { years. }\end{array}$ & $\begin{array}{l}\text { Weight, height and } \\
\text { BMI Evaluated } \\
\text { the speed growth } \\
\text { and comparison } \\
\text { between groups. } \\
\text { Cooperative Study } \\
\text { of Sickle Cell } \\
\text { Disease }\end{array}$ & $\begin{array}{l}\text { Growth speed }\left(\mathrm{cm} / \text { year) }{ }^{\circ} \mathrm{HbSS} \text { and }\right. \\
\left.\mathrm{HbS}^{\beta} \text { thalassemia (mean } \pm \text { DP }\right): 9.19 \\
\pm 2.98(n=16) \text { vs. control: } 8.46 \pm 2.64 \\
(n=27)^{\beta} \mathrm{HbSS} \text { and } \mathrm{HbS}^{\beta} \text { thalassemia } \\
(\text { mean } \pm \text { DP): } 12.02 \pm 3.41(n=8) \text { vs. } \\
\text { control: } 8.70 \pm 2.49(n=16)\end{array}$ \\
\hline
\end{tabular}




\begin{tabular}{|c|c|c|c|c|}
\hline $\begin{array}{l}\text { Nogueira, et al. } \\
2015 \\
\text { Brazil [6] }\end{array}$ & $\begin{array}{l}357 \mathrm{HbSS} \text { and } \mathrm{HbSC} \\
\text { children/2 to } 6 \text { years } \\
\text { (average: } 3.7 \text { years)/cross- } \\
\text { sectional and descriptive } \\
\text { study. }\end{array}$ & $\begin{array}{l}\text { Describing the } \\
\text { history of maternal } \\
\text { breastfeeding and } \\
\text { the anthropometry of } \\
\text { children with SCD, } \\
\text { with early diagnosis } \\
\text { and obtained by } \\
\text { neonatal screening, } \\
\text { followed up at a } \\
\text { referral service in } \\
\text { neonatal screening } \\
\text { of a state with a } \\
\text { high incidence of } \\
\text { hemoglobinopathies. }\end{array}$ & $\begin{array}{l}\text { Weight/age, } \\
\text { Height/age and } \\
\text { Weight/height }\end{array}$ & $\begin{array}{l}\text { For eutrophic children, mean MBF time } \\
\text { was almost four times higher than for } \\
\text { malnourished children }(p<0.01) \text { and } \\
5 \% \text { of children presented height deficit. } \\
\text { HbSS: } 94.72 \% \text { normal; } 4.2 \% \text { short } \\
\text { stature; } 1.0 \% \text { severe short stature } \\
\text { HbSC: } 95.2 \% \text { normal; } 4.8 \% \text { short } \\
\text { stature } \\
\text { HbSS: } 93.8 \% \text { normal; } 3.1 \% \\
\text { malnourished; } 3.1 \% \text { risk of overweight/ } \\
\text { overweight/obesity } \\
\text { HbSC: } 89.2 \% \text { normal; } 1.2 \% \\
\text { malnourished; } 9.6 \% \text { risk of overweight/ } \\
\text { obesity. }\end{array}$ \\
\hline $\begin{array}{l}\text { Eke, et al. } 2015 \\
\text { Nigeria [7] }\end{array}$ & $\begin{array}{l}58 \mathrm{HbSS} \text { children/ } 1 \text { to } 5 \\
\text { years and } 4 \text { months }(\mathrm{HbSS} \\
\text { average age: } 40.55 \pm 16.79 \\
\text { months (12-68 months); } \\
\text { Control: } 40.02 \pm 17.12 \\
\text { months (12-66 months)/ } \\
\text { cross-sectional and } \\
\text { descriptive study. }\end{array}$ & $\begin{array}{l}\text { Determining the } \\
\text { prevalence of } \\
\text { obesity in pre-school } \\
\text { children with sickle } \\
\text { cell anemia observed } \\
\text { at the University of } \\
\text { Nigeria Teaching } \\
\text { Hospital (UNTH), } \\
\text { Ituku-Ozalla, Enugu, } \\
\text { Southeast Nigeria. }\end{array}$ & $\begin{array}{l}\text { Weight/age, } \\
\text { Height/age and } \\
\text { BMI/A } \\
\text { WHO, 2006, } 2007\end{array}$ & $\begin{array}{l}\text { Mean BMI: HbSS: } 15.38 \pm 1.93 \text { vs. } \\
\text { control: } 17.10 \pm 2.28 \\
\text { Thiness or severe thiness: HbSS: } \\
12.1 \% \text { vs. control: } 0 \% \text { Overweight: } \\
\text { HbSS: } 17.2 \% \text { vs. control: } 16 \% \\
\text { Obesity: HbSS: } 3.4 \% \text { vs. control: } 22.4 \%\end{array}$ \\
\hline $\begin{array}{l}\text { Kazadi, et al. } \\
2017 \\
\text { Democratic } \\
\text { Republic of the } \\
\text { Congo [25] }\end{array}$ & $\begin{array}{l}256 \text { HbSS children (mean: } \\
8.4 \pm 4.9 \text { years)/cross- } \\
\text { sectional and descriptive } \\
\text { study. }\end{array}$ & $\begin{array}{l}\text { To investigate and } \\
\text { determine the risk } \\
\text { factors associated } \\
\text { with low growth } \\
\text { among HbSS } \\
\text { children. }\end{array}$ & $\begin{array}{l}\text { Weight/age, } \\
\text { Height/age and } \\
\text { Weight/height } \\
\text { WHO, } 2006\end{array}$ & $\begin{array}{l}\text { History of hand-foot syndrome and } \\
\text { more than } 3 \text { transfusions per patient } \\
\text { were associated with an increased age } \\
\text { were associated with an increased risk } \\
\text { of malnutrition. } \\
\text { Low stature: HbSS } 34.9 \% \text { vs. control: } \\
9.8 \% \\
\text { Low weight: HbSS: } 39.6 \% \text { vs. control: } \\
12.2 \% \\
\text { Growth retardation: HbSS: } 34.6 \% \text { vs. } \\
\text { control: } 9.8 \%\end{array}$ \\
\hline
\end{tabular}

HbSS: Sickle Cell Anemia; HbSC: Hemoglobinopathy SC; HbS ${ }^{\beta}$ Thalassemia: Beta Thalassemia; SCD: Sickle Cell Disease; SCA: Sickle Cell Anemia; CT: Computed Tomography; GH: Growth Hormone; IGF-1: Insulin-like Growth Factor type I; IGFBP-3: IGF Binding Protein-3; GHD: Growth Hormone Deficiency; WHO: World Health Organization; BMD: Bone Mineral Density; BMC: Bone Mineral Content; HCT: Hematopoietic Cells Transplant; HU: Hydroxyurea; BMI: Body Mass Index; Hb: Hemoglobin; FHb: Fetal Hemoglobin; Zn: Zinc; Ca: Calcium; RDI: Recommended Daily Intake; RDI: Reference Dietaty Intake; ZS: Z score; BMI: Body Mass Index; H/A: Height to Age; W/H: Weight to Height; W/A: Weight to Age; BMI/A: Body Mass Index to Age; ${ }^{\circ}$ : Boys; ${ }^{\circ}:$ Girls, CAR: Haplotypes type CAR (Central Africa Republic); Ben: Benin Type Haplotypes; LTE: Long-Term Erythrocytapheresis; EBF: Exclusive Breastfeeding.

group of the individuals, the nutritional status parameters, the prevalence of nutritional parameter classifications and the described factors that interfered in the nutritional status.

\section{Results}

\section{Study characteristics}

Predominantly the studies type was descriptive $(n=$ 34) with great variation in the sample number (from 8 to 675 participants) and in age (between 0 to 19 years old) (Table 1).

\section{Study results}

The studies applied varied the growth evaluation parameters. In addition, we observed the use of weight in 15 studies; of stature in 18 studies and of anthropometrics indicators in most studies (Height/age $(H / A)$ in 17 studies, Weight/age (W/A) in 13, Weight/height (W/H) in 11 and Body mass index/age (BMI/A) in 9).

We employed the National Center for Health Statistics (NCHS) reference standards in 19 studies and the World Health Organization (WHO) 2006-2007 in 6 studies regarding anthropometric indicators. In 13 studies, we used children with sickle cell anemia (SCA) data's and in one study used Tanner classification of 1976.

\section{Prevalence of nutritional status changes}

The height and weight deficit values vary from $8.2 \%$ to $34.9 \%$ and from $3.7 \%$ to $100 \%$ respectively, and overweight vary from $1.6 \%$ to $22.4 \%$. The emergence of weight and height compromise seems to be early, as we see in Stevens, et al. [3], which observed weight and height deficit before the age of 2 years on children with SCA. However, we observed overweight/obesity pres- 
ence mostly as of $2011^{\prime}$ s published studies [4-7].

\section{Associated factors with nutritional status}

The associated factors with growth deficit were resting energy expenditure (REE) [8] increase; Low mineral bone density [9-13]; Plasma concentration of micronutrients decrease [11,13-17]; Low concentration of hemoglobin [4,5,9,18-20]; The low food intake; Hormonal alterations [13,21-24], Vessel occlusion crises and increased need of transfusion [25].

However, the associated factor with overweight was the biggest $\mathrm{Hb}$ concentration, indicating the best disease prognosis, according to Chawla, et al. study [4]. Bone mineral density (BMD) was assessed in five studies. Dietary intake of micronutrients in 4 studies (vitamins $B 12$ and $A$ in 1 study, vitamin $C$ in 1 study, vitamin $\mathrm{D}$ and calcium $(\mathrm{Ca})$ in 3 studies, zinc $(\mathrm{Zn})$, iron $(\mathrm{Fe})$ and folic acid in 1 study). Zn plasma concentration in 2 studies. Serum levels of $\mathrm{Ca}$ in 2 studies and vitamin $\mathrm{D}$ in 3 studies.

The presence of low BMD varied between $14 \%$ and $56 \%$; Low calcium and vitamin $D$ intake varied between $48 \%$ and $75 \%$; Low serum zinc concentration between 15 and $44 \%$ moreover vitamin $D$ between $66 \%$ and $100 \%$.

\section{Discussion}

This review found the following results: a) The magnitude of short stature ranged from $8.2 \%$ to $24 \%$ and low weight from $3.7 \%$ to $100 \%$; b) The presence of overweight or obesity is already detected between $1.6 \%$ and $22.4 \%$; c) The factors associated with the growth deficit described in the articles were: Increased resting energy expenditure around $17 \%$ and nutritional deficiencies (low calcium and vitamin D intake between $48 \%$ and 75\%; Low serum zinc concentration between 15 and $44 \%$, vitamin D between $66 \%$ and $100 \%$ ); d) Other factors described (presence of low bone mineral density between $14 \%$ and $56 \%$, low Hb concentration, transfusions frequency and onset, complications frequency such as vessel occlusion and hand-foot syndrome, and the presence of hormonal alterations.

\section{Abstract of evidences}

The weight and length at birth of the child with SCD are usually normal and change until the end of the first year of life, culminating with low weight and short stature in childhood [2]. However, the child can reach normal height in adolescence, because the growth spurt occurs late due to delay in the closure of the epiphyses, which allows the recovery of stature in the adult phase $[2,26]$. As for short stature, it usually was associated with low bone mineral density [10-12] and the deficiency of some micronutrients such as zinc $[15,16]$, calcium [12] and vitamin D [11,12].

The Kazadi study [25] noted that the increased risk of short stature was related to a history of hand-foot syndrome and to the need for more than three transfusions per patient, in addition, malnutrition with vessel occlusion crises higher to two per year and the need for the first blood transfusion before 12 months old.

Evaluation of growth used different reference standards, with the NCHS growth curve being the most used, since they were twenty-one studies prior to the publication of the 2006 and 2007 WHO growth curve. However, regardless of the standard used, the weight and height deficits were prevalent in children and adolescents with SCD $[3-7,13,14,17,18,20,25,27-33]$.

In contrast, the predominance of normal and the presence of overweight or obesity observed in the more recent studies $[4,6,7,17,19]$ changes the nutritional profile of this group. These findings are important and possibly results of improved health care for people with sickle cell disease and changes in diet for the world's population.

The existence of extremes, namely of growth deficit or overweight/obesity, reinforces the need to monitor nutritional status, once both may aggravate the pathological conditions of children and adolescents with SCD, favoring a higher contraction of infections $[2,34]$ and respiratory complications [2,34].

Some factors affected nutritional status, such as clinical variables (hemoglobin concentration), disease progression (cardiac output and erythropoiesis increase, favoring REE increase), nutritional factors (low food intake and micronutrient depletion) and the type of treatment implemented.

In Bennett's study [35] four factors identified contributed to the delayed growth of children with SCA: Endocrine dysfunction, hypermetabolism, inadequate food intake, and micronutrient deficiencies, which reinforces the results found in this review.

The increase in REE $[8,36]$ directly contributes to the increase in energy needs, since it corresponds to $65 \%$ to $70 \%$ of the total daily energy expenditure [37]. Therefore, it can lead to the growth deficit only or when associated with a decrease in food consumption, common in hospitalized children for allergic crisis [8]. Individual nutritional monitoring of the child should be implemented in order to minimize hyperoxia, increase daily energy consumption and, consequently, restore nutritional status.

Furthermore, lack attention in the monitoring of essential micronutrients for child growth, which are commonly low in consumption, such as calcium $[11,12]$ and vitamin $D[12,16]$ or that were in low serum concentration, such as zinc $[14,15]$ and vitamin $D[11,12,16]$ increases the risk of malnutrition. Therefore, they need to be monitored during the nutritional follow-up. Micronutrient depletion contributes to the onset of low bone mineral density [11,12], of delays in skeletal maturation and growth deficit [15]. The importance of this monitor- 
ing was evident in the randomized clinical study which, when supplementing children with SCA with $10 \mathrm{mg}$ of elemental $\mathrm{Zn}$ for 12 months, showed significant stature gain [15].

Adequate clinical follow-up of the person with SCD usually results improvement in hemoglobin concentration. Adequate levels of hemoglobin in these patients, as evidence shows, avoid important complications such as aplastic crisis, splenic sequestration crisis, stroke, among others [27]. In addition, it was also observed that children with lower $\mathrm{P} / \mathrm{I}$ were those with lower $\mathrm{Hb}$ concentration [19]; And those with higher $\mathrm{Hb}$ concentrations [5] were associated with overweight and obesity, as well as with the use of hydroxyurea (HU) $[8,38]$ and continuous blood transfusion [21]. Endocrine compromise is also one of the factors that interferes with these children's growth. Those with SCD and low stature had low basal IGF-1 [21-24] concentrations and/or IGF-binding protein-3 (IGFBP-3) $[21,23,24]$ and/or growth hormone $(\mathrm{GH})$ deficient [21-23]. The deficiency of these hormones relates to slow growth and short stature in children with SCA, however, the $\mathrm{Ca}$, the micronutrient involved in growth, was normal in evaluated children [21]. Soliman, et al. [22] identified the presence of empty turmeric saddle in all children who had GH deficiency, which is suggestive of ischemic lesion in the pituitary gland. Therefore, in the persistence of nutritional deficits it is necessary to investigate these hormones.

In relation to the studied treatments [8,19,38-40], these seem to positively impact on growth and development by improving the clinical picture of the disease. However, should be noted that the studies with $\mathrm{HU}$ $[8,38,39,41]$ had a small sample number, ranging from 8 to 84 patients and short follow-up periods, from 4 months to 2 years. The results with the HU use in the nutritional state ranged from no difference in growth velocity [36] to weight gain, height $[8,39]$ and fat free mass [41].

Another treatment, hematopoietic cell transplantation (HCT) seems to not impair growth [40,42], but it is not advisable to perform it in the next period or during the growth spurt of adolescence $[40,43]$. The association between growth deficiency and HCT may be related partly to gonadal toxicity due to the busulfan (BU) doses administered. The likelihood of growth speed reduction is higher if the inhibitory effect of $\mathrm{BU}$ on gonadal function is exercised before the completion of the pubertal growth peak or the institution of hormone replacement therapy [40]. Despite this study [40] did not describe growth improvement with transplantation, it brings important contributions in guiding the most appropriate moment for its realization, in order to avoid losses in growth. Walters, et al. [42] observed improvement in linear growth after transplantation, however, they described the adverse effect of BU on the ovarian function of five of seven girls evaluated with age above 13 years old.
The different treatments evaluated presented benefits or minimized the growth deficit; However, more studies are necessary to evaluate the late effects of each type of treatment. Early diagnosis and appropriate treatment can reduce or avoid complications of the disease, so it is extremely important to follow up with professionals from different specialties, as well as the family and the community to know about the disease and its basic care [44].

The present study evidenced a high prevalence of weight and height deficits in this group, existing, although, the presence of overweight/obesity in those with better clinical conditions. The main factors associated with the growth deficit were described, which may lead to a more adequate clinical practice, since it makes it possible to prevent the occurrence of both growth and obesity deficits. Therefore, evidence-based interventions designated to prevent and minimize these changes in nutritional status.

\section{Limitations}

The studies analyzed have several methodological limitations. First, most studies have a wide breadth of age, mixing infants, preschoolers, schoolchildren, adolescents, and young adults. Secondly, they did not investigate the action of different physio pathological and therapeutic aspects in the same group of children and adolescents. Third, there was a variability of several growth reference standards, which did not allow the comparison of the data. Finally, there was a predominance of descriptive cross-sectional studies, which did not allow to conjecture a possible time line between the associated factors and the compromising of nutritional status.

\section{Acknowledgements}

Profa. Dra. Denise Giacomo da Motta.

\section{Competing Interests}

The authors declare that they have no conflict of interest.

\section{Author's Contributions}

Design: Cláudia dos Santos Cople-Rodrigues; Samara Agda dos Santos; Data analysis and interpretation: Samara Agda dos Santos; Cláudia dos Santos Cople-Rodrigues; Cecilia Lacroix de Oliveira; Review and approval of the final version of the article: Cláudia dos Santos Cople -Rodrigues; Samara Agda dos Santos; Cecilia Lacroix de Oliveira; Paulo Ivo Cortez.

\section{References}

1. (2006) Manual of Basic Behavior in Sickle Disease. Ministry of Health, Department of Health care, Department of Specialized Attention, Brazil.

2. (2002) Manual of diagnosis and treatment of sickle diseases. National Health Surveillance Agency, ANVISA, Brazil. 
3. Stevens MC, Maude GH, Cupidore L, Jackson H, Hayes RJ, et al. (1986) Prepubertal growth and skeletal maturation in children with sickle cell disease. Pediatrics 78: 124-132.

4. Chawla A, Sprinz PG, Welch J, Heeney M, Usmani N, et al. (2013) Weight status of children with sickle cell disease. Pediatrics 131: e1168-e1173.

5. Souza KCM, Araújo PIC, Souza-Junior PRB, Lacerda EMA (2011) Stunting and wasting in children and adolescents with sickle cell disease. Rev Nutr 24: 853-862.

6. Nogueira ZD, Boa-Sorte N, Leite MEQ, Kiya MM, Amorim T, et al. (2015) Breastfeeding and the anthropometric profile of children with sickle cell anemia receiving follow-up in a newborn screening reference service. Rev Paul Pediatr 33: 154-159.

7. Eke CB, Edelu BO, Ikefuna NA, Emodi IJ, Ibe BC (2015) Obesity in preschool-aged children with sickle cell anemia emerging nutritional challenge in a resource limited setting. Pediatr Hematol Oncol 32: 390-398.

8. Fung EB, Barden EM, Kawchak DA, Zemel BS, Ohene-Frempong K, et al. (2001) Effect of hydroxyurea therapy on resting energy expenditure in children with sickle cell disease. J Pediatr Hematol Oncol 23: 604-608.

9. Rhodes M, Akohoue SA, Shankar SM, Fleming I, Qi An A, et al. (2009) Growth patterns in children with sickle cell anemia during puberty. Pediatr Blood Cancer 53: 635-641.

10. Fung EB, Kawchak DA, Zemel BS, Rovner AJ, Ohene-Frempong K, et al. (2008) Markers of bone turnover are associated with growth and development in young subjects with sickle cell anemia. Pediatr Blood Cancer 50: 620-623.

11. Lal A, Fung EB, Pakbaz Z, Hackney-Stephens E, Vichinsky EP (2006) Bone mineral density in children with sickle cell anemia. Pediatr Blood Cancer 47: 901-906.

12. Buison AM, Kawchak DA, Schall JI, Ohene-Frempong K, Stallings VA, et al. (2005) Bone area and bone mineral content deficits in children with sickle cell disease. Pediatrics 116: 943-949.

13. Özen S, Ünal S, Erçetin N, Taşdelen B (2013) Frequency and risk factors of endocrine complications in Turkish children and adolescents with sickle cell anemia. Turk J Haematol 30: 25-31.

14. Leonard MB, Zemel BS, Kawchak DA, Ohene-Frempong K, Stallings VA (1998) Plasma zinc status, growth, and maturation in children with sickle cell disease. J Pediatr 132 467-471.

15. Zemel BS, Kawchak DA, Fung EB, Ohene-Frempong K, Stallings VA (2002) Effect of zinc supplementation on growth and body composition in children with sickle cell disease. Am J Clin Nutr 75: 300-307.

16. Buison AM, Kawchak DA, Schall J, Ohene-Frempong K, Stallings VA, et al. (2004) Low vitamin D status in children with sickle cell disease. J Pediatr 145: 622-627.

17. Pinho L de, Azevedo $C$ do A, Caldeira AP, Amaral J F do (2012) Antrhopometric and dietary patterns of children with sickle cell disease. Rev Baiana Saúde Pública 36: 935-950.

18. Silva CM, Viana MB (2002) Growth deficits in children with sickle cell disease. Archives of Medical Research 33: 308312.

19. Wang WC, Morales KH, Scher CD, Styles L, Olivieri N, et al. (2005) Effect of long-term transfusion on growth in children with sickle cell anemia: Results of the STOP trial. J Pediatr 147: 244-247.
20. Zemel BS, Kawchak DA, Ohene-Frempong K, Schall JL, Stallings VA (2007) Effects of delayed pubertal development, nutritional status, and disease severity on longitudinal patterns of growth failure in children with sickle cell disease. Pediatr Res 61: 607-613.

21. Soliman AT, el Banna N, alSalmi I, De Silva V, Craig A, et al. (1997) Growth hormone secretion and circulating insulin-like growth factor-I (IGF-I) and IGF binding protein-3 concentrations in children with sickle cell disease. Metabolism 46: 1241-1245.

22. Soliman AT, Darwish AL, Asfour MG (1995) Empty sella in short children with and without hypothalamic-pituitary abnormalities. Indian J Pediatr 62: 597-603.

23. Luporini MS, Bendit I, Manhani R, Bracco OL, Manzella L, et al. (2001) Growth hormone and insulin-like growth factor I axis and growth of children with different sickle cell anemia haplotypes. J Pediatr Hematol Oncol 23: 357-363.

24. Collett-Solberg PF, Fleenor D, Schultz WH, Ware RE (2007) Short stature in children with sickle cell anemia correlates with alterations in the IGF-I axis. J Pediatr Endocrinol Metab 20: 211-218.

25. Kazadi AL, Ngiyulu MN, Gini-Ehungu JL, Mbuyi-Muamba JM, Aloni MN (2017) Factors associated with growth retardation in children suffering from sickle cell anemia: First Report from Central Africa. Anemia.

26. Singhal A, Thomas P, Cook R, Wierenga K, Serjeant $G$ (1994) Delayed adolescent growth in homozygous sickle cell disease. Arch Dis Child 71: 404-408.

27. Cipolotti R, Caskey MFB, Franco RP, Mello EV, Dal Fabbro AL, et al. (2000) Childhood and adolescent growth of patients with sickle cell disease in Aracaju, Sergipe, northeast Brazil. Ann Trop Paediatr 20: 109-113.

28. Nikhar HS, Meshram SU, Shinde GB (2012) An anthropometric and hematological comparison of sickle cell disease children from rural and urban areas. Indian J Hum Genet 18: 40-42.

29. Warrier RP, Kuvibidila S, Gordon L, Humbert J (1994) Transport proteins and acute phase reactant proteins in children with sickle cell anemia. J Natl Med Assoc 86: 3339.

30. Animasahun BA, Temiye EO, Ogunkunle OO, Izuora AN, Njokanma DE (2011) The influence of socioeconomic status on the hemoglobin level and anthropometry of sickle cell anemia patients in steady state at the Lagos University Teaching Hospital. Niger J of Clin Pract 14: 422-427.

31. Dougherty KA, Schall JI, Rovner AJ, Stallings VA, Zemel BS (2011) Attenuated maximal muscle strength and peak power in children with sickle cell disease. J Pediatr Hematol Oncol 33: 93-97.

32. Barden EM, Kawchak DA, Ohene-Frempong K, Stallings VA, Zemel BS (2002) Body composition in children with sickle cell disease. Am J Clin Nutr 76: 218-225.

33. Bavle A, Raj A, Kong M, Bertolone S (2014) Impact of LongTerm Erythrocytapheresis on Growth and Peak Height Velocity of Children With Sickle Cell Disease. Pediatr Blood Cancer 61: 2024-2030.

34. (2012) Sickle cell disease: Basic management for treatment. Ministry of Health, Department of Attention to Health, Department of Specialized Attention, Brazil.

35. Bennett EL (2011) Understanding growth failure in children with homozygous sickle-cell disease. J Pediatr Oncol Nurs 28: 67-74. 
36. Singhal A, Parker S, Linsell L, Serjeant G (2002) Energy intake and resting metabolic rate in preschool Jamaican children with homozygous sickle cell disease. Am J Clin Nutr 75: 1093-1097.

37. Rodríguez G, Moreno LA, Sarría A, Pineda I, Fleta J, et al. (2002) Determinants of resting energy expenditure in obese and non-obese children and adolescents. J Physiol Biochem 58: 9-15.

38. de Montalembert M, Belloy M, Bernaudin F, Gouraud F, Capdeville R, et al. (1997) Three-year follow-up of hydroxyurea treatment in severely ill children with sickle cell disease. J Pediatr Hematol Oncol 19: 313-318.

39. Wang WC, Helms RW, Lynn HS, Redding-Lallinger R, Gee BE, et al. (2002) Effect of hydroxyurea on growth in children with sickle cell anemia: Results of the HUG-KIDS Study. J Pediatr 140: 225-229.

40. Eggleston B, Patience M, Edwards S, Adamkiewicz T, Buchanan GR, et al. (2007) Effect of myeloablative bone marrow transplantation on growth in children with sickle cell anaemia: Results of the multicenter study of hematopoietic cell transplantation for sickle cell anemia. $\mathrm{Br} \mathrm{J}$ Hematol 136: 673-676.

41. Kinney R, Helms RW, O’Branski EE, Ohene-Frempong K, Wang W, et al. (1999) Safety of hydroxyurea in children with sickle cell anemia: Results of the HUG-KIDS Study, a Phase I/II Trial. Blood 94: 1550-1554.

42. Walters MC, Storb R, Patience M, Leisenring W, Taylor T, et al. (2000) Impact of bone marrow transplantation for symptomatic sickle cell disease: An interim report. Multicenter investigation of bone marrow transplantation for sickle cell disease. Blood 95: 1918-1924.

43. Simões BP, Pieroni F, Barros GMN, Machado CL, Cançado RD, et al. (2010) Brazilian consensus meeting on stem cell transplantation: Hemoglobinopathies comittee. Rev Bras Hematol Hemoter 32: 46-53.

44. (2001) Manual of the most important diseases, for ethnic reasons, in the Afrodescendant Brazilian population. Ministry of Health, Department of Health Policies, Brazil. 